\title{
Erigeron sumatrensis Retz. (Compositae), a recently recognized invasive alien species in Bosnia and Herzegovina
}

\author{
SEMIR MASLO ${ }^{1 *}$, ŠEMSO ŠARIĆ \\ ${ }^{1}$ Primary School, Lundåkerskolan, Södra Storgatan 45, 33233 Gislaved, Sweden \\ ${ }^{2}$ Jelaške, Olovo, Bosnia and Herzegovina
}

*Autor za dopisivanje / corresponding author: semmas@edu.gislaved.se

Tip članka / article type: kratko stručno priopćenje / short professional communication Povijest članka / article history: primljeno / received: 13.10.2020., prihvaćeno / accepted: 10.12.2020. URL: https://doi.org/10.46232/glashbod.8.2.3

Maslo, S., Šarić, Š. (2020): Erigeron sumatrensis Retz. (Compositae), a recently recognized invasive alien species in Bosnia and Herzegovina. Glas. Hrvat. bot. druš. 8(2): 88-93.

\section{Abstract}

Erigeron sumatrensis Retz. is native in South America, widely naturalized in Europe and has been recently recorded in Bosnia and Herzegovina. During the period of 2019-2020, it was recorded at 35 new localities in South Herzegovina and Central Bosnia. On the basis of the number of populations and the numbers of individuals within populations, we assume that this species is now invasive in Bosnia and Herzegovina.

Keywords: alien plants, Bosnia and Herzegovina, distribution, Erigeron, invasive

Maslo, S., Šarić, Š. (2020): Erigeron sumatrensis Retz. (Compositae), nova invazivna vrsta u flori Bosne i Hercegovine. Glas. Hrvat. bot. druš. 8(2): 88-93.

\section{Sažetak}

Erigeron sumatrensis Retz. je vrsta porijeklom iz Južne Amerike, široko naturalizirana u Europi, a nedavno je zabilježena u Bosni i Hercegovini. Tijekom razdoblja 2019. - 2020. zabilježena je na novih 35 lokaliteta u južnoj Hercegovini i srednjoj Bosni. Na osnovu broja populacija i broja jedinki unutar populacija, pretpostavljamo da je ova vrsta danas invazivna u Bosni i Hercegovini.

Ključne riječi: Bosna i Hercegovina, Erigeron, invazivne vrste, rasprostranjenost, strane vrste

\section{Introduction}

The genus Erigeron L. is represented by 45 species in the Euro-Mediterranean region (Greuter 2006). Some species of the genus with reduced ligule length of ray florets and decreased number of hermaphroditic disk florets relative to female ray florets are derived from within the genus Erigeron into a separate genus Conyza Less (Cronquist 1943, Nesom 2008). This segregation is not supported by molecular data (Noyes 2000). In Anglo-American countries, Conyza is mostly treated as a separate genus following Cronquist (1943). In Europe, Conyza is now associated with Erigeron (Greuter 2003). 
Seven species of the genus Erigeron have been recorded in the flora of Bosnia and Herzegovina (Beck von Mannagetta et al. 1983, Lasić et al. 2010, Milanović 2019) of which four are alien: Erigeron annuus (L.) Desf., E. bonariensis L., E. canadensis and E. sumatrensis Retz. (Maslo et al. 2020). All alien species of the genus Erigeron in Bosnia and Herzegovina, except E. sumatrensis, have already been included in the Preliminary list of invasive alien plant species (IAS) in Bosnia and Herzegovina (Maslo 2016).

Table 1. First literature and herbarium records of alien species of the genus Erigeron in Bosnia and Herzegovina.

\begin{tabular}{lll}
\hline Species & Literature records & Herbarium records \\
\hline E. annuus & Fojnica, Murbeck 1891 & Hreljevo (Sarajevo), Fiala 1887 (SARA-41077) \\
\hline E. bonariensis & Mostar, Lasić et al. 2010 & No herbarium records in SARA \\
\hline E. canadensis & Blagaj, Struschka 1880 & Travnik, Brandis 1884 (SARA-41096) \\
\hline E. sumatrensis & Neum, Milanović 2019 & No herbarium records in SARA
\end{tabular}

The species Erigeron sumatrensis Retz. (syn. Conyza sumatrensis (Retz.) E. Walker, C. albida Spreng., C. naudinii Bonnet) is native to South America, from where it has spread to the warmer regions of all continents, except for Antarctica, and is now probably among the most widespread species found throughout the world. In Europe it occurs primarily in waste dumps, fields, vineyards, along roadsides and railways, but also in disturbed areas of native vegetation, and in natural sand dunes or grasslands (Thébaud \& Abbot 1995).

The first record from Europe relates to France in the second part of the $19^{\text {th }}$ century, as Conyza naudinii Bonnet (Bonnet 1878). Soon after, the plant began to spread rapidly across Europe. It has been recorded in most countries of Southern and Western Europe as well as in some countries of Central Europe (Greuter 2006). In the Balkan Peninsula, E. sumatrensis has been recorded in Greece (Danin 1976), Albania (Baltisberger \& Lippert 1987), European Turkey (Davis et al. 1988), Croatia (Čarni 1996, Milović 2004), Slovenia (Čarni 1996), Serbia (Niketić \& Jovanović 2002), Bulgaria (Vladimirov 2009), Montenegro (Stešević \& Petrović 2010) and North Macedonia (Vladimirov et al. 2016). This species is referred to as invasive in all neighboring countries: Croatia (Boršić et al. 2008), Montenegro (Stešević \& Petrović 2010) and Serbia (Stojanović \& Jovanović 2018).
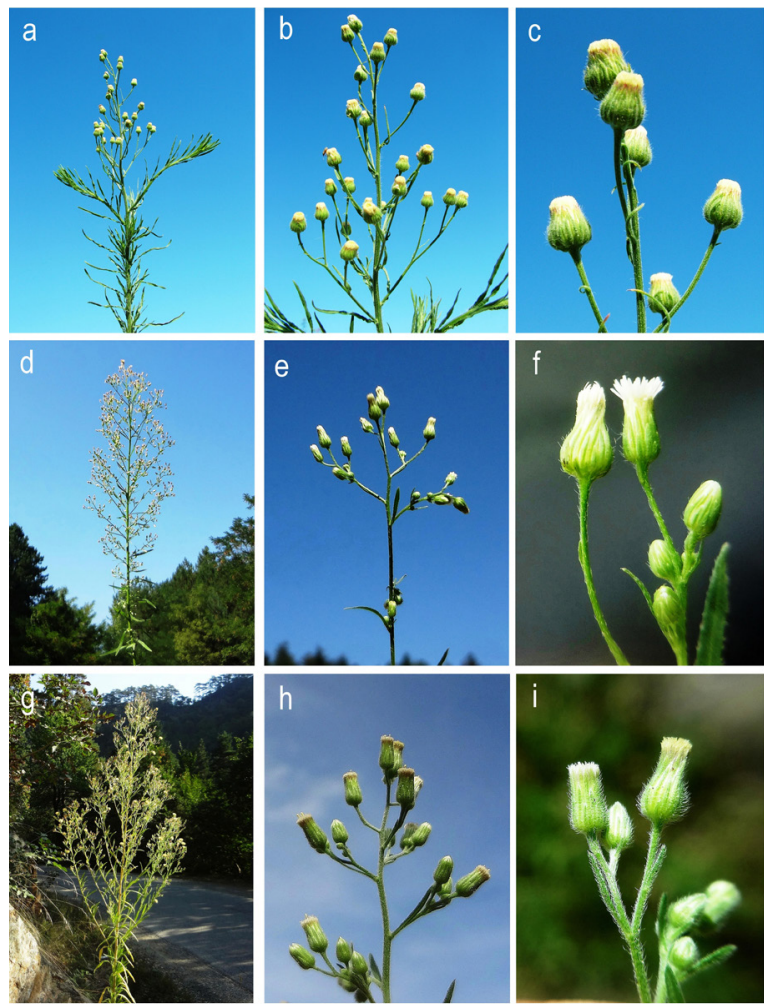

Figure 1. Erigeron bonariensis - inflorescence (A), E. bonariensis - part of inflorescence (B), E. bonariensis - capitulum (C), E. canadensis - inflorescence (D), E. canadensis - part of inflorescence (E), E. canadensis capitulum (F), E. sumatrensis - inflorescence (G), E. sumatrensis - part of inflorescence $(\mathrm{H})$, E. sumatrensis - capitulum (I) (Photos A-C: S. Maslo, D-I: Š. Šarić). 
Erigeron sumatrensis (Fig. 1) is a stout, annual herb that has fibrous roots and can grow to be $200 \mathrm{~cm}$ tall. Its stem is grayish-green, erect, much branched from the base, with dense, simple non-glandular hairs. Basal leaves form a rosette, lanceolate to oblanceolate, $4-18 \times 0.3-3.0 \mathrm{~cm}$, margins deeply lobed, yellowish-green or grayish-green, densely hirsute on margins and midrib. Cauline leaves numerous, alternate, characteristically narrowly lanceolate-elliptic to lanceolate or oblanceolate, 3-10 $x 0.5-2 \mathrm{~cm}$. The inflorescence is rhombic in outline, widely and profusely branched, the lateral branches not overtopping the main axis, finely grey-pubescent throughout, not glandular. Mature capitula 5-7 $\mathrm{mm}$ long, involucres hirsute-pilose. Short ligulate flowers present, very short, less than $0.5 \mathrm{~mm}$ long, inconspicuous (not exceeding the involucres). Papus pale brown (2n=54) (Vladimirov 2009).

The first attempt of this study was to elucidate the presence of E. sumatrensis in Bosnia and Herzegovina, widely confused with $E$. bonariensis and $E$. canadensis. A subsidiary goal was to obtain an overview of all alien taxa of the genus Erigeron in Bosnia and Herzegovina, based on literature references, and of revision of the Herbarium of the National Museum of Bosnia and Herzegovina (SARA) and field records.

The field study was conducted in the summer of 2019 and 2020. Digital photographs and GPS coordinates were taken in the field. The determination and morphological description of the species were based on Wurzell (1988) and Verloove (2019). The nomenclature follows Greuter $(2003,2006)$. The distribution of the species in Bosnia and Herzegovina is shown on the map using standard UTM grid $10 \times 10 \mathrm{~km}$ (Fig. 2). Its invasiveness status was determined using the terminology according to Richardson et al. (2000). Data on the abundance of E. sumatrensis, trends of its populations and characteristics of the habitats where it grows in Bosnia and Herzegovina were obtained in the course of fieldwork. The specimens from Banovići (Mačkovac) and Olovo (Buk) were collected and stored in the SARA collection (SARA51991, SARA-51992).

\section{Results and discussion}

In the SARA collection, 42 specimens of the alien taxa of genus Erigeron were previously stored (26 specimens of E. annuus and 16 specimens of $E$. canadensis). With a detailed overview of the herbarium collection SARA we have found that all stored specimens were correctly identified. In the herbarium collection SARA there are no specimens of $E$. bonariensis or $E$. sumatrensis from Bosnia and Herzegovina.

The first record of E. sumatrensis in Bosnia and Herzegovina dates from 2019, when it was discovered on the Klek peninsula near the town of Neum in Southern Herzegovina (Milanović 2019).

The most morphologically similar species (in Balkans) to E. sumatrensis are E. bonariensis and E. canadensis. Correct identification of these species can be problematic due to their morphological similarities. To separate these three species, we offer the adjusted key according to Wurzell (1988) and Verloove (2019).

1 Leaves nearly glabrous above or with scattered hairs along midrib only, margins distinctly ciliate. Involucral bract nearly glabrous. Capitula ca. 2-4 $\mathrm{mm}$ wide at anthesis. Lamina of ligular florets present, erect, $0.5-1 \mathrm{~mm}$ long, white. Pappus brownish

E. canadensis

1 Leaves densely shortly pubescent above, margins hardly ciliate. Involucral bracts densely hairy. Capitula ca. 5-10 mm wide at anthesis. Lamina of ligular florets absent or inconspicuous ............... 2

2 Leaves narrow, less than $5 \mathrm{~mm}$ wide, the uppermost linear. Inflorescence often with greatly enlarged side branches overtopping the main axis. Apex of involucral bracts often purplish. Capitula ca. 6-10 $\mathrm{mm}$ at anthesis. Ligules absent. Pappus whitish

E. bonariensis

2 Most leaves wider, 3-20 mm wide, never linear. Side branches of the inflorescence not overtopping the main axis. Apex of involucral bracts not purplish. Capitula ca. 5-7 mm at anthesis. Ligules very short, less than $0.5 \mathrm{~mm}$ long. Pappus brownish ..... 
Table 2. Georeferenced data of the distribution of Erigeron sumatrensis in Bosnia and Herzegovina (data from literature are in bold).

\begin{tabular}{|c|c|c|c|c|}
\hline $\begin{array}{l}\text { Number of } \\
\text { quadrant }\end{array}$ & $\begin{array}{l}\text { Number and name of the } \\
\text { locality }\end{array}$ & WGS coordinates & Altitude & $\begin{array}{l}\text { UTM } \\
\text { quadrant }\end{array}$ \\
\hline 1 & 1 Živinice, Golubinjak & $44^{\circ} 27^{\prime} 12^{\prime \prime} \mathrm{N}, 18^{\circ} 38^{\prime} 58^{\prime \prime} \mathrm{E}$ & $215 \mathrm{~m}$ & CQ12 \\
\hline 2 & 2 Banovići, Omazići & $44^{\circ} 25^{\prime} 01^{\prime \prime} \mathrm{N}, 18^{\circ} 32^{\prime} 38^{\prime \prime} \mathrm{E}$ & $343 \mathrm{~m}$ & CQ02 \\
\hline 3 & 3 Zavidovići & $44^{\circ} 26^{\prime} 35^{\prime \prime} \mathrm{N}, 18^{\circ} 08^{\prime} 58^{\prime \prime} \mathrm{E}$ & $206 \mathrm{~m}$ & BQ72 \\
\hline 3 & 4 Zavidovići, Kovači & $44^{\circ} 26^{\prime} 20^{\prime \prime} \mathrm{N}, 18^{\circ} 13^{\prime} 35^{\prime \prime} \mathrm{E}$ & $226 m$ & BQ72 \\
\hline 4 & 5 Žepče, Ljeskovica & $44^{\circ} 25^{\prime} 00^{\prime \prime} \mathrm{N}, 18^{\circ} 06^{\prime} 14^{\prime \prime} \mathrm{E}$ & $222 \mathrm{~m}$ & BQ62 \\
\hline 5 & 6 Žepče, Želeća & $44^{\circ} 23^{\prime} 51^{\prime \prime} \mathrm{N}, 17^{\circ} 59^{\prime} 31^{\prime \prime} \mathrm{E}$ & $241 \mathrm{~m}$ & YK32 \\
\hline 5 & 7 Žepče, Ograjina & $44^{\circ} 25^{\prime} 08^{\prime \prime} \mathrm{N}, 17^{\circ} 58^{\prime} 41^{\prime \prime} \mathrm{E}$ & $313 \mathrm{~m}$ & YK32 \\
\hline 6 & 8 Banovići & $44^{\circ} 23^{\prime} 11^{\prime \prime} \mathrm{N}, 18^{\circ} 33^{\prime} 01^{\prime \prime} \mathrm{E}$ & $335 \mathrm{~m}$ & CQ01 \\
\hline 6 & 9 Banovići, Mačkovac & $44^{\circ} 23^{\prime} 13^{\prime \prime} \mathrm{N}, 18^{\circ} 33^{\prime} 02^{\prime \prime} \mathrm{E}$ & $335 \mathrm{~m}$ & CQ01 \\
\hline 6 & 10 Živinice, Ježevac & $44^{\circ} 24^{\prime} 18^{\prime \prime} \mathrm{N}, 18^{\circ} 33^{\prime} 55^{\prime \prime} \mathrm{E}$ & $342 \mathrm{~m}$ & CQ01 \\
\hline 7 & 11 Zavidovići, Stipin Han & $44^{\circ} 19^{\prime} 20^{\prime \prime} \mathrm{N}, 18^{\circ} 25^{\prime} 24^{\prime \prime} \mathrm{E}$ & $320 m$ & BQ91 \\
\hline 7 & 12 Zavidovići, Male Ribnice & $44^{\circ} 21^{\prime} 02^{\prime \prime} \mathrm{N}, 18^{\circ} 26^{\prime} 01^{\prime \prime} \mathrm{E}$ & $395 \mathrm{~m}$ & BQ91 \\
\hline 7 & 13 Zavidovići, Donja Gosovica & $44^{\circ} 20^{\prime} 40^{\prime \prime} \mathrm{N}, 18^{\circ} 28^{\prime} 40^{\prime \prime} \mathrm{E}$ & $293 m$ & BQ91 \\
\hline 7 & 14 Banovići, Velike Ribnice & $44^{\circ} 21^{\prime} 13^{\prime \prime} \mathrm{N}, 18^{\circ} 27^{\prime} 50^{\prime \prime} \mathrm{E}$ & $468 \mathrm{~m}$ & BQ91 \\
\hline 8 & 15 Zavidovići, Stošnica potok & $44^{\circ} 22^{\prime} 58^{\prime \prime} \mathrm{N}, 18^{\circ} 18^{\prime} 38^{\prime \prime} \mathrm{E}$ & $331 \mathrm{~m}$ & $\mathrm{BQ81}$ \\
\hline 9 & 16 Žepče, Begov Han & $44^{\circ} 20^{\prime} 56^{\prime \prime} \mathrm{N}, 17^{\circ} 59^{\prime} 25^{\prime \prime} \mathrm{E}$ & $258 m$ & YK31 \\
\hline 10 & 17 Zavidovići, Maoča & $44^{\circ} 18^{\prime} 12^{\prime \prime} \mathrm{N}, 18^{\circ} 24^{\prime} 42^{\prime \prime} \mathrm{E}$ & $338 \mathrm{~m}$ & BQ90 \\
\hline 10 & 18 Olovo, Buk & $44^{\circ} 17^{\prime} 30^{\prime \prime} \mathrm{N}, 18^{\circ} 25^{\prime} 28^{\prime \prime} \mathrm{E}$ & $356 m$ & BQ90 \\
\hline 10 & 19 Olovo, Careve Ćuprija & $44^{\circ} 16^{\prime} 25^{\prime \prime} \mathrm{N}, 18^{\circ} 25^{\prime} 37^{\prime \prime} \mathrm{E}$ & $381 \mathrm{~m}$ & BQ90 \\
\hline 10 & 20 Olovo, Vojnica & $44^{\circ} 15^{\prime} 52^{\prime \prime} \mathrm{N}, 18^{\circ} 24^{\prime} 22^{\prime \prime} \mathrm{E}$ & $464 m$ & BQ90 \\
\hline 10 & 21 Olovo, Župeljeva & $44^{\circ} 17^{\prime} 14^{\prime \prime} \mathrm{N}, 18^{\circ} 26^{\prime} 41^{\prime \prime} \mathrm{E}$ & $439 m$ & BQ90 \\
\hline 11 & 22 Vareš, Kopališta & $44^{\circ} 13^{\prime} 34^{\prime \prime} \mathrm{N}, 18^{\circ} 18^{\prime} 43^{\prime \prime} \mathrm{E}$ & $934 \mathrm{~m}$ & $\mathrm{BQ80}$ \\
\hline 12 & 23 Konjic, Bradina & $43^{\circ} 44^{\prime} 27^{\prime \prime} \mathrm{N}, 18^{\circ} 01^{\prime} 29^{\prime \prime} \mathrm{E}$ & $774 \mathrm{~m}$ & BP64 \\
\hline 13 & 24 Konjic, Čelebići & $43^{\circ} 41^{\prime} 00^{\prime \prime} \mathrm{N}, 17^{\circ} 53^{\prime} 54^{\prime \prime} \mathrm{E}$ & $285 \mathrm{~m}$ & YJ34 \\
\hline 14 & 25 Donja Jablanica & $43^{\circ} 37^{\prime} 47^{\prime \prime} \mathrm{N}, 17^{\circ} 45^{\prime} 53^{\prime \prime} \mathrm{E}$ & $169 \mathrm{~m}$ & YJ23 \\
\hline 15 & 26 Mostar, Podhum & $43^{\circ} 20^{\prime} 16^{\prime \prime} \mathrm{N}, 17^{\circ} 48^{\prime} 09^{\prime \prime} \mathrm{E}$ & $69 \mathrm{~m}$ & YJ20 \\
\hline 15 & 27 Mostar, Pasjak & $43^{\circ} 21^{\prime} 00^{\prime \prime} \mathrm{N}, 17^{\circ} 48^{\prime} 50^{\prime \prime} \mathrm{E}$ & $76 \mathrm{~m}$ & YJ20 \\
\hline 15 & 28 Mostar, Sjeverni logor & $43^{\circ} 21^{\prime} 28^{\prime \prime} \mathrm{N}, 17^{\circ} 48^{\prime} 32^{\prime \prime} \mathrm{E}$ & $62 \mathrm{~m}$ & YJ20 \\
\hline 16 & 29 Blagaj, Vrelo Bune & $43^{\circ} 15^{\prime} 21^{\prime \prime} \mathrm{N}, 17^{\circ} 54^{\prime} 07^{\prime \prime} \mathrm{E}$ & $48 \mathrm{~m}$ & YH39 \\
\hline 17 & 30 Ljubuški, Koćuša & $43^{\circ} 14^{\prime} 53^{\prime \prime} \mathrm{N}, 17^{\circ} 27^{\prime} 10^{\prime \prime} \mathrm{E}$ & $92 \mathrm{~m}$ & XH99 \\
\hline 18 & 31 Stolac, Radimlja & $43^{\circ} 05^{\prime} 33^{\prime \prime} \mathrm{N}, 17^{\circ} 55^{\prime} 24^{\prime \prime} \mathrm{E}$ & $60 \mathrm{~m}$ & YH37 \\
\hline 19 & 32 Hutovo Blato, Karaotok & $43^{\circ} 03^{\prime} 58^{\prime \prime} \mathrm{N}, 17^{\circ} 45^{\prime} 09^{\prime \prime} \mathrm{E}$ & $5 \mathrm{~m}$ & $\mathrm{YH} 27$ \\
\hline 19 & 33 Počitelj & $43^{\circ} 08^{\prime} 05^{\prime \prime} \mathrm{N}, 17^{\circ} 43^{\prime} 49^{\prime \prime} \mathrm{E}$ & $16 \mathrm{~m}$ & YH27 \\
\hline 20 & 34 Čapljina, Mogorjelo & $43^{\circ} 05^{\prime} 58^{\prime \prime} \mathrm{N}, 17^{\circ} 42^{\prime} 06^{\prime \prime} \mathrm{E}$ & $6 \mathrm{~m}$ & YH17 \\
\hline 21 & 35 Neum & $42^{\circ} 55^{\prime} 27^{\prime \prime} \mathrm{N}, 17^{\circ} 36^{\prime} 42^{\prime \prime} \mathrm{E}$ & $2 \mathrm{~m}$ & YH15 \\
\hline 21 & 36 Poluotok Klek, Tanko sedlo & $42^{\circ} 55^{\prime} 05^{\prime \prime} \mathrm{N}, 17^{\circ} 35^{\prime} 40^{\prime \prime} \mathrm{E}$ & $47 \mathrm{~m}$ & YH15 \\
\hline 21 & 37 Poluotok Klek, Crna ljut & $42^{\circ} 55^{\prime} 04^{\prime \prime} \mathrm{N}, 17^{\circ} 35^{\prime} 57^{\prime \prime} \mathrm{E}$ & $52 \mathrm{~m}$ & YH15 \\
\hline 22 & 38 Poluotok Klek, Opuće & $42^{\circ} 55^{\prime} 45^{\prime \prime} \mathrm{N}, 17^{\circ} 34^{\prime} 13^{\prime \prime} \mathrm{E}$ & $8 \mathrm{~m}$ & YH05 \\
\hline
\end{tabular}


According to the literature data and herbarium materials stored in the SARA collection, and our own field study, we could conclude that $E$. annuus and $E$. canadensis are widely distributed species on the whole territory of Bosnia and Herzegovina. On the other hand, E. bonariensis and E. sumatrensis were only present in the Mediterranean part of the country. New data on distribution of $E$. sumatrensis in Bosnia and Herzegovina indicate that the invasion character of this species is becoming more pronounced. Although until recently it was found only on one locality in South Herzegovina, the new data also indicate its presence in Central Bosnia. This species reaches high abundance of individuals in all new localities in Bosnia and Herzegovina, inhabiting various ruderal habitats within human settlements.

The currently known distribution of $E$. sumatrensis is estimated to 38 localities (Fig. 2, Tab. 2) with some populations of several hundred individuals. In the territory of Bosnia and Herzegovina, $E$. sumatrensis mostly appears on well-trodden ground along local roads, pavements, asphalt and concrete areas, and in ruderal habitats within settlements, as well on sand and gravel riverbanks. Considering the present wide distribution and abundance of the species in the country, it has probably been introduced at least a decade ago.

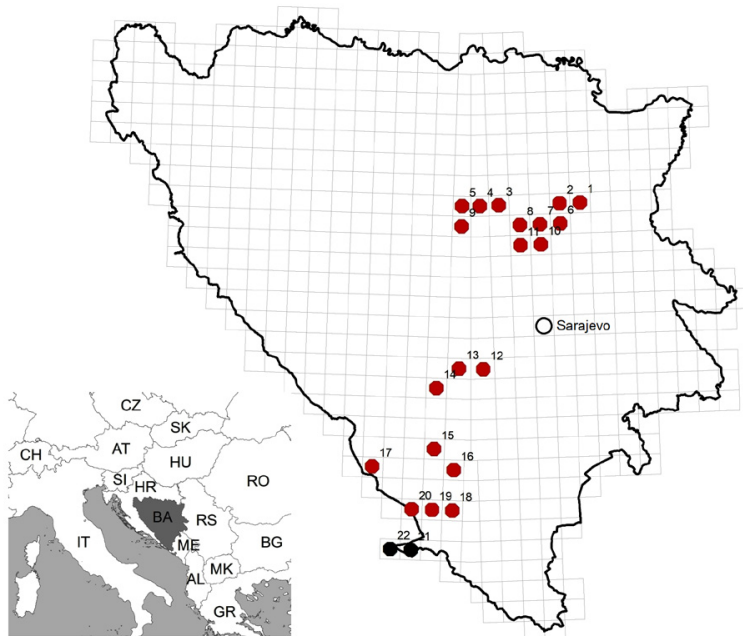

Figure 2. The distribution of Erigeron sumatrensis Retz. in Bosnia and Herzegovina where old records are black circles and new records are red circles.
The obtained results indicate that E. sumatrensis can be considered an invasive alien species in the territory of Bosnia and Herzegovina, in the sense of Richardson et al. (2000).

\section{Acknowledgements}

Authors would like to thank Ermana Lagumdžija and Nermina Sarajlić for the help during studying of the SARA collection, Aldin Boškailo for the mapping of distribution of the species and Lanna Maslo for improving the English of this paper.

\section{References}

Baltisberger, M., Lippert, W. (1987): Compositen aus Albanien. Candollea 42: 679-691.

Beck von Mannagetta, G., Malý, K., Bjelčić, ž. (1983): Flora Bosnae et Hercegovinae, 4 Sympetalae, 4. National Museum of Bosnia and Herzegovina, Sarajevo.

Bonnet, M. (eds.) (1878): Notes sur quelques plantes du midi de la France. Bulletin de la Société botanique de France 25: 205-210.

Boršić, I., Milović, M., Dujmović, I., Bogdanović, S., Cigić, P., Rešetnik, I., Nikolić, T., Mitić, B. (2008): Preliminary check-list of invasive alien plant species (IAS) in Croatia. Natura Croatica 17: 55-71.

Čarni, A. (1996): Thermophilic vegetation of trampled habitats in Istria (Croatia and Slovenia). Biologia 51: 405-409.

Cronquist, A. (1947): Revision of the North American species of Erigeron, north of Mexico. Brittonia 6: 121-300.

Danin, A. (1976): On three adventive species of Conyza (Compositae) in Greece. Candollea 31: 107-109.

Davis, P.H., Mill, R.R., Tan, K. (1988): Flora of Turkey and the East Aegean Islands. Vol. 10, Supplement. Edinburgh Universitet Press, Edinburgh.

Greuter, W. (2006+): Compositae (pro parte majore). In: Greuter, W., Raab-Straube, E. von (eds.): Compositae. Euro+Med Plantbase - the information resource for Euro-Mediterranean plant diversity. [accessed September 2020]. 
Greuter, W. (2003): The Euro+Med treatment of Astereae (Compositae) - generic concepts and required new names. Willdenowia 33: 45-47.

Lasić, A., Jasprica, N., Ruščić, M. (2010): Neophytes in the city of Mostar (Bosnia and Herzegovina). In: Jasprica, N., Pandža, M., Milović, M.(eds.): Book of Abstracts of Third Croatian Botanical Congress with international participation, Hrvatsko botaničko društvo, Murter-Zagreb, 121.

Maslo, S. (2016): Preliminary list of invasive alien plant species (IAS) in Bosnia and Herzegovina. Herbologia 16(1): 1-14.

Maslo, S., Wong, L.J., Pagad, S. (2020): GRIIS Checklist of Introduced and Invasive Species - Bosnia and Herzegovina. Version 1.3. Invasive Species Specialist Group ISSG. Checklist dataset. www. gbif.org. (accessed September 2020).

Milanović, Đ. (2019:) Novelties for the flora of Bosnia and Herzegovina from Klek peninsula. In: Ranđelović, V., Stojanović-Radić, Z., Nikolić, D. (eds.): 13th Symposium on the Flora of Southeastern Serbia and Neighboring Regions, Department of Biology and Ecology, Faculty of Science and Mathematics, University of Niš, 51.

Milović, M. (2004): Naturalised species of the genus Conyza Less. (Asteraceae) in Croatia. Acta Botanica Croatica 63(2): 147-170.

Murbeck, S. (1891): Beitrage zur Kenntnis der Flora von Sudbosnien und der Hercegovina. Lunds Universitets Arsskrift 27: 1-182.

Nesom, G.L. (2008): Classification of subtribe Conyzinae (Asteraceae: Astereae). Lundellia 11: 8-38.

Niketić, M., Jovanović, S. (2002): Conyza sumatrensis, a new adventive species in the flora of Serbia. In: Proceeding of the 7th Syposium on Flora and Vegetation of Southeastern Serbia and neighbouring regions. Dimitrovgrad, 23.

Noyes, R.D. (2000): Biogeographical and evolutionary insights on Erigeron and allies (Asteraceae) from ITS sequence data. Plant Systematics and Evolution 220: 93-114.
Raab-Straube, E. Von, Raus, Th. (eds.) (2017): Euro+Med-Checklist Notulae, 8 [Notulae ad floram euromediterraneam pertinentes No. 37]. Willdenowia 47: 293-309.

Richardson, D. M., Pyšek, P., Rejmánek, M., Barbour, M. G., Panetta, F. D., West, C. J. (2000): Naturalization and invasion of alien plants: concepts and definitions. Diversity \& Distributions 6: 93-107.

Stešević, D., Petrović, D. (2010): Preliminary list of plant invaders in Montenegro. Biologica Nyssana 1(1-2): 35-42.

Stojanović, V., Jovanović, I. (2018): The survey of invasive and potentially invasive plant species in Serbia and neighbouring countries for the purpose of determining their status at the national level. Nature Conservation 68(1-2): 41-59.

Struschka, H. (1880): Die umgebung Mostars, eine geographisch-naturwissenschaftliche Studie. Programm des K.K. Staatsgymnasium in Kremsier, 1879/80: 1-44.

Thébaud, Ch., Abbot, R.J. (1995): Characterization of invasive Conyza species (Asteraceae) in Europe: quantitative trait and isozyme analysis. American Journal of Botany 82: 360-368.

Verloove, F. (2019): Erigeron. In: Manual of the Alien Plants of Belgium. Botanic Garden of Meise, Belgium. At http://alienplantsbelgium. be (accessed September 2020).

Vladimirov, V. (2009): Erigeron sumatrensis (Asteraceae): a recently recognized alien species in the Bulgarian flora. Phytologia Balcanica 15(3): 361-365.

Vladimirov, V., Matevski, V., Bancheva, S., Delcheva, M., Kostadinovski, M., Ćušterevska, R. (2016): First report of Erigeron sumatrensis (Asteraceae) for the flora of the Republic of Macedonia. Flora Mediterrannea 26: 203-207.

Wurzell, B. (1988): Conyza sumatrensis (Retz.) E. Walker established in England. Watsonia 17: 145-148. 